\title{
Correction to: Ultrasound localization of lacerated flexor tendon ends in the hand: a cadaveric study
}

\author{
David A. Alvarez ${ }^{1} \cdot$ David H. Ballard $^{2}$ (1) $\cdot$ Trevor Carroll $^{1} \cdot$ Clifton Frilot $^{3} \cdot$ Alberto A. Simoncini $^{4}$
}

Published online: 10 June 2019

(C) ISS 2019

\section{Correction to: Skeletal Radiology \\ https://doi.org/10.1007/s00256-019-03237-6}

In the results section of the abstract, it states " $99.0 \%(\mathrm{n}=05 /$

96 tendons)" when it should state "99.0\% ( $\mathrm{n}=95 / 96$ tendons)".

Publisher's note Springer Nature remains neutral with regard to jurisdictional claims in published maps and institutional affiliations.

The online version of the original article can be found at https://oi.org/ 10.1007/s00256-019-03237-6

David H. Ballard

davidballard@wustl.edu

David A. Alvarez

dalvar@1suhsc.edu

Trevor Carroll

tcarrol12@gmail.com

Clifton Frilot

cfrilo@1suhsc.edu

Alberto A. Simoncini

asimon@1suhsc.edu
Department of Orthopedics, LSUHSC-Shreveport, 1501 Kings Highway, Shreveport, LA 71103, USA

2 Mallinckrodt Institute of Radiology, Washington University School of Medicine, 510 S. Kingshighway Blvd, Campus Box 8131, St. Louis, MO 63110, USA

3 Department of Rehabilitation Sciences in the School of Allied Health Professions, LSUHSC-Shreveport, 1501 Kings Highway, Shreveport, LA 71103, USA

4 Department of Radiology, LSUHSC-Shreveport, 1501 Kings Highway, Shreveport, LA 71103, USA 